\title{
"A More Permanent Familiarity": Value and the Paternal Image on United States Currency
}

Heinz Tschachler

\section{(2) OpenEdition \\ Journals}

Electronic version

URL: https://journals.openedition.org/ejas/14562

DOI: 10.4000/ejas.14562

ISSN: 1991-9336

Publisher

European Association for American Studies

\section{Electronic reference}

Heinz Tschachler, "'A More Permanent Familiarity": Value and the Paternal Image on United States Currency", European journal of American studies [Online], 14-2 | 2019, Online since 06 July 2019, connection on 08 July 2021. URL: http://journals.openedition.org/ejas/14562 ; DOI: https://doi.org/ 10.4000/ejas. 14562

This text was automatically generated on 8 July 2021.

Creative Commons License 


\title{
"A More Permanent Familiarity": Value and the Paternal Image on United States Currency
}

\author{
Heinz Tschachler
}

\section{Introduction}

1 When in 2014 an advocacy group by the name of "Women on 20s" began to lobby the administration for a redesign of the current $\$ 20$ bill to bear the portrait of a woman, many Americans were hopeful. The suggested redesign provided that the portrait of an "exemplary American woman" would replace Andrew Jackson's. The woman who was finally selected as the face for the new $\$ 20$ bill is Harriet Tubman (c.1822-1913). Born into slavery, Harriet Tubman escaped to the North and became a conductor in the Underground Railroad, helping slaves to escape to freedom. During the Civil War, she was active in the Union cause, serving as a nurse, a cook, and a scout, gathering intelligence (cf. Women on 20s). Design changes are at the sole discretion of the Treasury Secretary. There is, however, no evidence that then Secretary Jacob L. Lew had taken any action by the time he handed the keys over to his successor, Steven T. Mnuchin, in January 2017. At the time it also was not yet known how the Trump administration would approach the currency redesign, though there was considerable concern about a rollback. More than two years into the Trump presidency, no details about the new designs have been released, and Women on 20s are concerned that the Treasury Department may not hit the target of the actual bill designs in time to honor the centennial of women's suffrage, with rollout of the bills into circulation later by years (cf. Women on 20s).

2 The last word in the matter has not been spoken, though it may not even come from Secretary Mnuchin but from President Donald J. Trump. Given President Trump's notorious unpredictability, there is no certainty about the "Tubmans" (or any other redesigns); all we know with a measure of certainty is that identity politics is not one of 
President Trump's priorities. Additionally, Trump is on record as expressing great admiration for Andrew Jackson, calling him, through a spokesman, "an amazing figure in American history-very unique in many ways," and, on the occasion of a visit to Jackson's plantation home, "the people's president," whose victory "shook the establishment like an earthquake" ("Trump's Remarks"; Greenwood). It is also a matter of record that right after his inauguration President Trump hung a portrait of Andrew Jackson in the Oval Office, as "inspiration" (Haberman). And when the planned redesign of the $\$ 20$ bill was officially announced in April 2016, Donald Trump said in response that bumping Andrew Jackson on the $\$ 20$ bill was "pure political correctness," suggesting that Harriet Tubman be put on the $\$ 2$ bill instead, to replace Thomas Jefferson. For Trump, Jackson "had a great history" and so, he added, it would be "very rough" to take him off the bill (qtd. in Frizell). Given Trump's preferences, it is no surprise that nothing has happened so far. And considering Trump's willful ignorance and his sly efforts to insidiously sabotage and discredit, if not altogether destroy government, we should not expect any action soon. Instead, we should look at the failure to redesign the currency as part of an utterly dystopic endgame.

3 A portrait of a woman on the currency no doubt would instill in Americans a better understanding of the impact women have made in the country's history. In this respect, the currency redesign would be a chance to teach the citizenry, and this may well have been the motivation of the previous administration. Moreover, a currency redesign is a chance to respond to the spirit of the time and, by way of an attempt to seek legitimacy with its citizens, to make the government produce a design that strengthens identification between the state and the people. There is, however, a more fundamental question: Would a portrait of a woman on the currency make any substantive difference? Would it help undermine or terminate the real power of men in society? The presidential election of 2016 is a point in case here. It is "not customary to have women lead or even to engage in the rough-and-tumble of politics," Hillary Clinton writes in her memoir of her unsuccessful campaign. "It's not normal-not yet. So when it happens, it often doesn't feel quite right. That may sound vague, but it's potent. People cast their votes based on feelings like that all the time" (224-25). The statement shows that Hillary Clinton was well aware of a basic problem, one that Uri Friedman formulated in The Atlantic right after election day-that "to win in a presidential system, women must contend more directly, and on a larger scale, with sexism and stereotypes." What this means is nothing less that Donald Trump defeated Hillary Clinton not so much because she stood for the establishment, intellectualism, or an exaggerated concern for questions of feminism, gender, and diversity, all of which would have made her the "wrong" woman. Hillary Clinton lost the election because of her being a woman.

4 The point is that not just Hillary Clinton but "any woman who had been the first to run for president with the backing of a major party would have encountered some of the gender-based scrutiny Clinton faced" (Gordon-Reed 13). They would have encountered that scrutiny for at least two reasons. One is that many Americans, especially white men, felt that women had upended their world and that they now had a chance to vent their anger and frustration. The other reason is that Americans' expectations for their political leaders have been set by generations of male politicians and shaped by generations of male pundits. Unable to escape the gender trap, Hillary Clinton was always perceived first and foremost as a woman, and only secondarily as a serious politician. In the televised debates with Donald Trump, for instance, Trump presented 
himself as the one to bring back "jobs," at the same time as he insinuated that Hillary Clinton "only talks," is "all talk" (Second Presidential Debate). Altogether, as a woman running for the presidency Hillary Clinton lacked the freedom to nonchalantly ride over social ideals of male power. Instead, she kept tapping into prevailing attitudes towards women, especially about the role of women in a matrix of feelings and the collective unconscious of a large part of the American electorate. ${ }^{1}$

The story of the nation's currency too is a gendered narrative as well as a narrative of gender. Nor is Andrew Jackson the only prospective casualty in efforts to tinker with the currency. America's lawmakers for the past thirty years or so have repeatedly attempted to replace the one-dollar bill with Washington's image on it with a coin. In the 1990s, for instance, their endeavors found encouragement from a special interest group called "The Coin Coalition." At the other end were the Mount Vernon Ladies' Association and, more vociferously, "Save the Greenback," an organization of Bureau of Engraving and Printing employees and paper and ink suppliers opposed to phasing out the one-dollar bill and replacing it with a coin. More recently, another dollar bill phaseout was contested by a group that called itself "Americans for George." In opposition to the COINS Act (the acronym stands for "Currency Optimization, Innovation, and National Savings Act"), which was introduced in the House of Representatives in September 2011, web postings and tweets habitually pointed to the one-dollar bill's "national symbolism, much of which dates to the founding of the nation," trumpeted the bill as a "uniquely American icon," or wanted Washington's "memory live on via the \#dollarbill!" (cf. Americans for George). Following the CoINS Act's introduction, it was immediately referred to the House Committee on Financial Services and, later, to the Subcommittee on Domestic Monetary Policy and Technology (United States Congress H.R.2977). No further action has been recorded, though this is not the end of the story. In July 2013 the late Senator John McCain took upon himself the task of keeping the matter alive when he addressed a meeting hosted by the CAGW (Council for Citizens Against Government Waste) and the Dollar Coin Alliance; two years later, McCain (together with Wyoming Senator Mike Enzi) proposed the USA Act (for "Unified Savings and Accountability"), which to date is the latest proposal to eliminate onedollar bills from circulation (United States Congress S.1888).

\section{Iconic Space, Public Space, and Women's Otherness}

6 Much has been written about the current one-dollar bill, and justifiably so. The note is truly unique. No other piece of currency, American or non-American, communicates such abundant information about the nation's history, the structure of the nation, and its highest goals and aspirations. The note's ceremonial load is of a rare visual opulence that at the same time preserves and protects its status as an iconic sign. The most prominent element in the bill's ritual freight no doubt is Gilbert Stuart's "Athenaeum" portrait of George Washington. Together with other visual and verbal signs and symbols, the 1796 portrait (in Gideon Fairman's version of it) serves to re-finance the one-dollar bill from realms outside the economy, politics, religion, and the arts. We might even say that the bill's seconding notions confer upon a lowly piece of paper a certain depth, a certain verticality, its ever-diminishing value notwithstanding. "Somewhere, a treasure is present, a reserve, a fund, upon which this bill is staked," the French scholar Jean-Joseph Goux suggested. "There exists an underlying, protected 
value, which the State holds, preserves, and guarantees by its institution, and which this bill represents" ("Cash, Check, or Charge?" 117). "Treasure" is only one possible translation of the French word trésor, which can also mean "treasury" and "thesaurus," a treasury of words. Still, the primary sense intended by Goux is a repository or reserve of wealth in the form of money or precious metal. The pertinence of "treasure" is owed to the shift, so central to Goux's extensive reading of André Gide's novel The Counterfeiters (Les faux-monnayeurs, 1925), "from a society founded on legitimation by representation to a society dominated by the inconvertibility of signifiers, that refer to one another like tokens in infinite slippage, with no standard or treasury to offer the guarantee of a transcendental signifier or referent" (The Coiners of Language 4).

In Gide's novel the monetary metaphor registers the fact that language, especially literary language, can no longer be compared to gold money, or even to paper money that is representative of gold. Reading the metaphor to itself registers the shift from representative paper money, which can be converted to precious metal, to fiat money, which is inconvertible and circulates only as forced currency (cf. Goux, The Coiners of Language 16 and chap.13, esp. 124-28). Thus, the treasure represented by the one-dollar note, its protected value, is gold, the "Lord of commodities," in Marx's words (166). Gold is, then, the general equivalent of all products, an idealized element against which all other elements measure their value. In the word "Lord," however, the two realms of Christian doctrine come together, the secular one of economic exchange (in which the dollar bill is merely a monetary token), and the divine one of the exchange of gifts (in which the bill is an infinitely large and archaic gift, which obligates the recipient to give back something, or at least to be grateful). The term "Lord of commodities" thus not only highlights the theological character of the monetary system but also, importantly, points to the accession of the father to the rank of privileged subject, the "general equivalent of subjects" against which all other elements (family members and, by extension, other people) measure their value against (Goux, Symbolic Economies 3-4, 12-21).

8 The "Lord of Commodities" is the economic equivalent of the Lord God, whose worship develops into an end in itself. His representative on earth is George Washington, the Father (founder), whose worship likewise developed into an end in itself, transforming him into "the sole reflecting image of all subjects seeking their worth" (Goux, Symbolic Economies 3). Goux's summary of the one-dollar bill's symbolic force is pertinent:

The State (and its Treasury), the Father (founder), God (and our faith in him), the dead and sacralized Language (Latin): all these powerful, central signifiers converge, combine, and intensify each other so as to provide the one-dollar note with its force. It is the State in all of its foundational stability that guarantees the value of the bill, under the authority of the Treasury. ("Cash, Check, or Charge?" 117)

9 What Goux does not mention is that the foundational stability provided by the masculine profile never left any place for women on the currency. A rare exception is the one-dollar Silver Certificate from 1896, which offered "an excellent picture of Martha Washington, the wife of the Father of His Country" ("Martha on $\$ 1$ ").

Charles Burt's head of Martha Washington made her the first and only named woman to appear on the primary portrait of United States currency. But the portrait, on the back of the Silver Certificate, also presents Martha Washington as adornment, George Washington's wife, the avatar of domesticity. In contrast, George Washington confronts 
the viewer as president, whose awe-inspiring air identifies him as the Father of His Country.

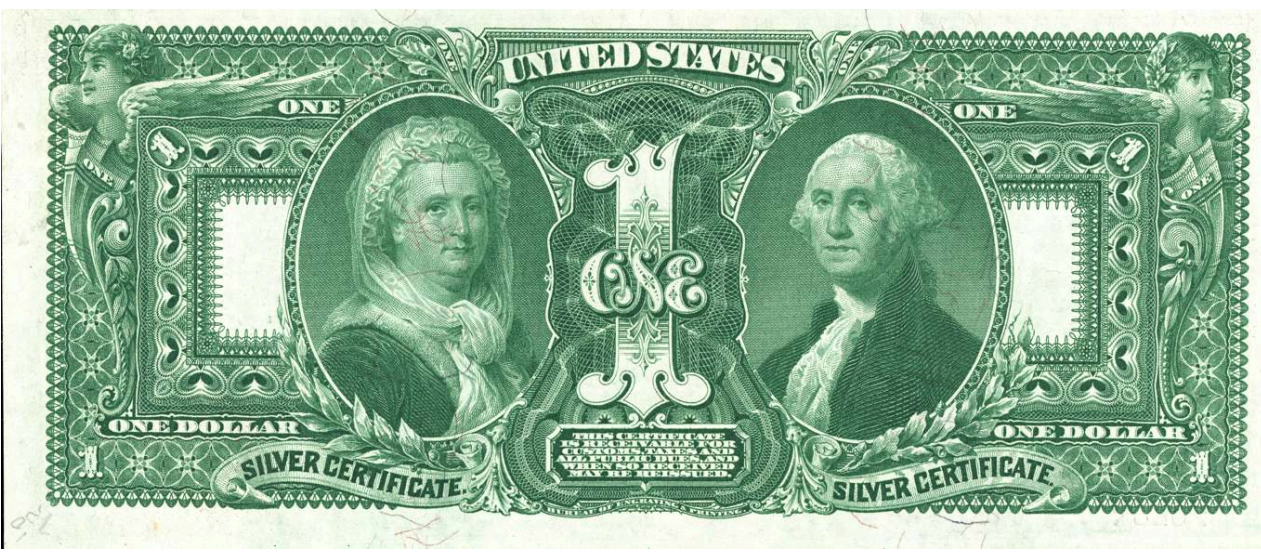

11 (Courtesy of the American Numismatic Association Money Museum)

12 On the bill, the two portraits are rigidly separated by the central numeral-" 1 ," also spelled out as an embellished "ONE"-, which hints at the gendered classification of separate spheres for men and women. Thus, the ensemble presents a seamless fit in a pictorial tradition that accepted real women only as the wives of their better-known husbands and that applied the opprobrium "masculine" to politically or intellectually active women. "I do not wonder," Abigail Adams had written in 1814, that "learned [women] are considered as black swans" (qtd. in Ferguson 182).

13 Abigail Adams's words reveal that the pattern of excluding women from the public sphere and reducing them to silence plagued the fledgling republic from its inception. "We know better than to repeal our Masculine systems," John Adams had responded to his wife's express desire, in March 1776, that the revolutionaries "would remember the Ladies, and be more generous and favourable to them than your ancestors." So sure was Abigail Adams's husband of the viability of the patriarchal system and so convinced was he of the necessity to keep all kinds of marginalized groups in place that he added:

\begin{abstract}
As to your extraordinary Code of Laws, I cannot but laugh. We have been told that our Struggle has loosened the bands of Government every where. That children and Apprentices were disobedient-that schools and Colledges were grown turbulentthat Indians slighted their Guardians and Negroes grew insolent to their Masters. But your letter was the first intimation that another Tribe more numerous and powerful than all the rest were grown discontented. (qtd. in Ferguson 152)
\end{abstract}

Among the revolutionary leaders, only Thomas Paine addressed women's rights in a different fashion. "Man with regard to [women], in all climates, and in all ages," he wrote in 1775, "has been either an insensible husband or an oppressor." Paine's contribution for the Pennsylvania Magazine also details the exclusion of women from public life: "[M]an, while he imposes duties upon women, would deprive them of the sweets of public esteem, and in exacting virtues from them, would make it a crime to aspire at honor." Still, women do not seize their rights in Paine's writings. They remain the supplicants of a masculine world of patriarchs. "Be not our tyrants in all," runs Paine's imagined version of this supplicating voice. "Permit our names to be sometimes pronounced beyond the narrow circles in which we live"' (qtd. in Ferguson 179). There is hardly a better example of the "narrow circles" in which women lived then than the English legal scholar William Blackstone's commentary on marriage: 
By marriage, the husband and wife are one person in law: that is, the very being or legal existence of the woman is suspended during the marriage... incorporated and consolidated into that of the husband: under whose wing, protection, and cover, she performs every thing; and is therefore called in our law-french, a feme-covert. (qtd. in Ferguson 160)

15 The "incorporation" of the woman's existence into that of the husband cannot be separated from the economic order that based value on property. It is important to point out here that by the time of the founders, property had come to mean not merely de facto possessions but de jure possessions over which owners had documented claims on the basis of which possessions could be sold, mortgaged, or loaned with a view of appropriate returns. The system of private property, specified and quantified in legally binding contracts, goes back a long way, to the beginning of the Greek polis and, later, to the Roman civitas. In each instance, feudal relations based on de facto possession gave way to economic contracts. In tandem with the ascent of private ownership, women lost their former status and became reduced to mere wards of their fathers, their husbands, even their brothers (cf. Harris 120). There was another, even more dire consequence, of private ownership. Property can be passed on undisputedly to the following generation (of sons) only if there is no doubt whatsoever about paternity. As Mary Poovey argues,

a woman's sexual infidelity challenged not only the security of the paternal relation and the man's exclusive right to property, but also the illusion that women were 'fixed' as reproductive (not sexually autonomous) beings, as dependent (not socially autonomous) subjects, and as uniformly 'other' to man[.] (80)

16 Women's otherness constitutes one term in the structural opposition in which the exchange between men and women is usually cast. Based as this exchange is on de jure possession and desire, women are mere objects to be exchanged, functionally equivalent to commodities and money, which likewise circulate among men. Their worth is not intrinsic but derives from their valuation by the male subject, his "imprint," which becomes the standard or étalonnage, in relation to a third. The French word étalon, as used by the feminist and cultural theorist Luce Irigaray, designates a stallion, a standard of measure, or a currency (étalon-or), thus pointing to the parallelism between sexual and financial exchanges. If femininity, for Irigaray, is premised on exclusion from control over money, language, and the gaze, masculinity is characterized by their possession. The masculine thus is the standard of value, in relation to which the feminine acquires significance and worth. This standardization, which divides the social order into masculine "producer subjects" and feminine "commodity-objects" makes the grounding of value in the paternal image problematic, much as it makes the proposed removal of the paternal image from the currency a more than ephemeral project (222; Boesenberg 160-61).

17 There is a gendered difference also in what money signifies. As the psychologists Adrian Furnham and Michael Argyle have shown, "women think of money in terms of the things into which it can be converted, while men think of it in terms of the power its possession implies" (40). For men, the two authors claim, money means happiness, excitement, respect, and reverence, its possession adding to their self-esteem, independence, and power. For all these reasons, men are more prepared to take financial risks and to speculate. Women, in contrast, seem rather afraid of money. For them, money often spells fear, depression, anger, panic, helplessness, even shame. And because they think of money as a means of purchasing things or making new relevant 
experiences, women tend to be more careful spending money. Above all, however, women seem to have difficulties talking about money, about how much they are making or about how much they are spending. Women, Furnham and Argyle contend, usually were and often still are kept in the dark about the household's financial situation. It does not come as a surprise that for many women, money is the currency of power and domination (cf. 24-25, 46-48).

Martha Washington on the $\$ 1$ Silver Certificates of 1896 is quite literally a "femme couverte" who, upon entering marriage, had received a "cover," to the effect that she was at the same time "protected" and "hidden" (Ferguson 180). Moreover, the word "ONE," spelled out over her portrait, not only evokes the many dissolving into one-E pluribus Unum-, but also a cruelly ironic reworking of Blackstone's commentary on marriage. The fragile and highly ambivalent gender idyll on the $\$ 1$ Silver Certificates of 1896 did not last long, though. \$1 Silver Certificates of later series, 1923 and 1928 (one of the first of the new small-size notes), altogether dispensed with Martha Washington. Whereas the wife vanished from the currency (she lived on in the pages of The Woman's Home Companion or Good Housekeeping, and she made a comeback on a 4 Cents postage stamp in 1922), the husband had been honored in his own right already on earlier issues. George Washington's portrait was centrally placed on the front of the $\$ 2$ Silver Certificates, Series 1899 , the year of the centennial of his death.

On the $\$ 2$ Silver Certificates, Series 1899, Washington's portrait appears between two allegorical figures, Mechanics (male) and Agriculture (female). The composition reveals a typical pattern in currency design. By and large, historic persons depicted on the currency are all men. And they are depicted through portraits. In contrast, full-size figures are usually allegories, male and female alike. Female allegories most often stand in as figurative symbols of liberty and republican virtue, an iconography that underscores women's passivity in public forums. Put differently, Liberty as well as republican virtue evoke a purity of status or innocence of experience under masculine protection, categories that preclude independent female activity. Currency notes thus faithfully register the classification of public and active versus private or domestic and passive that framed the traditional gender hierarchy and that also shaped the symbolic constitution of the United States. Male protagonists were coded as image carriers of the vita activa, while females appeared as mere showpieces, passive objects to be looked at (cf. Elshtain).

20 George Washington's portrait from the $\$ 2$ Silver Certificates, Series 1899, was used again for $\$ 1$ Federal Reserve Bank notes, series of 1918. The notes' backs were graced by a patriotic eagle in flight, grasping a flag-hence the nickname "Green Eagle Notes" (cf. Bowers 133-35). Clearly Washington's image signified the vita activa, much as it was to inspire patriotism at a time when the United States engaged their "relentless enemy in a life-and-death struggle." At such a time, a syndicated writer noted, "what Washington did and said, and caused to be done, [was] taking on a new and solemn meaning" (Schwartz 34). Ten years later, new currency notes also were taking on a new and solemn meaning. Earlier notes, the "Green Eagle Notes" included, were of considerable size-7.42 x 3.125 inches. Notes issued after 1928 are much smaller-6.14 x 2.61 inches. The new size was easier to handle and store, and the change also saved the Treasury millions of dollars (cf. Tschachler 181-82). The reduction in size-from "horse blankets" to "pocket change"-was not the only directive issued by Treasury Secretary Andrew W. Mellon. Mellon also acted on a committee recommendation to fundamentally 
redesign the visual order on existing notes. When the project was accomplished, the former flood of arbitrarily selected pictures had been curbed: Now there were only a few select examples of national architecture, a scene from the nation's history (the signing of the Declaration of Independence), and the portraits of "the Presidents of the United States."2

\section{Presidential Portraits and the Rhetoric of Political Fatherhood}

21 Portraits of "the Presidents of the United States," Secretary Mellon's special committee decided, "have a more permanent familiarity in the minds of the public than any others" (USBEP). ${ }^{3}$ One understands the sentiment. "No people," President Calvin Coolidge said in an address delivered in Fredericksburg, Virginia, on July 6, 1922, "can look forward who do not look backward" (173). President Coolidge's words provided a model for many Americans to seek, as the literary historian Alfred Kazin put it in 1939, "the comfort of their grandfathers" (qtd. in Marling 365). Indeed, the portraits of "the Presidents of the United States" on the redesigned currency were to offer a firm footing in the midst of social and economic chaos, tendering comfort and solace. The continuity, since 1929, of "Presidents" portraits should not therefore surprise anyone. Banknote design in general is a complex and sometimes opaque process. Decisionmaking is often nebulous, and the committees responsible for it are frequently composed on an ad-hoc basis. What is known is that form and content of banknote design are driven by safety concerns, stylistic conventions and ideologies and, not to forget, costs. The latter factor is especially true of money that is used worldwide. Globally used paper money like the dollar, Jacques Hymans suggested, "involves much higher transaction costs, including the cost of informing end-users of the changes and the cost of collecting the old bills for replacement. These costs may induce the hegemon to maintain its money's traditional "look"' (29).

There is another reason for the visual design of currency notes habitually being more "conservative" than that of stamps and other securities. ${ }^{4}$ Currency notes are generally considered a "state's calling cards," mirroring the values they represent as moneystability, continuity, and resilience to crises. ${ }^{5}$ This is especially true for U.S. currency. In the years following the currency reform heads of state, generals, and other statesmen gave way to representatives of official culture (composers like Verdi or Strauss, for instance). Internationally, that is, while U.S. currency remained unaffected by these changes. Although the practice of commemorating "Presidents" and other statesmen stopped when Woodrow Wilson's portrait was put on the $\$ 100,000$ bill in 1934, the reason was not ideological so much as practical, as the Bureau of Engraving and Printing simply ran out of denominations; moreover, the bills bearing all those prominent males still circulate (some bills have been discontinued, though, while the $\$ 100,000$ bill never circulated). On U.S. currency, therefore, the state as actor prevails, conveying to citizens the value of federal, that is, state-produced money and programs.

The "dead presidents," as dollar bills are colloquially called, provide a frequent reminder to people that they are to be members of what nationalists from all social strata consider an ethnically united community. Ever since the beginning of modern nation-states, authorities have relied on the mass immersion in the nationalistic iconography on the currency to mold people's identity and their perceived destiny, to 
teach what is expected from them, and, not to forget, to connect to the spirit of the age in an attempt to increase the state's legitimacy with its citizenry. ${ }^{6}$ In the United States, the currency reform of the 1920s transformed the nation's currency into "a reassuringly familiar quantity from coast to coast, a brand like the other brands already beginning to conquer and even define aspects of the nation. The dollar helped this happen. Uniformity drove down price: a clear price fostered uniformity" (Goodwin 287-88). One consequence of "uniformity" is that any change will be perceived as an intervention into an objectively existent world of things, with quite unsettling effects on note-holders. Resistance to change holds true especially of nations whose culturalpolitical constitution is based on popular sovereignty. In such nations, there also seems to exist a general aversion to currency designs that are contemporary or even avantgarde. In their stead, atavistic mythologies, metaphysical notions and iconographies are in great demand. The United States is no exception in this regard. Hence the perpetual reminder, on the currency, of the nation's grand old men-its "fathers," as it were-, which at one and the same time provides retrospective assurance and moves the source of power back to the state (cf. Pointon 229-54).

Among the nation's grand old men-its metaphorical "fathers"-one man stands out, George Washington. "The history of America is the history of Washington," the art historian Mark Thistlethwaite wrote (The Image of George Washington 3). Washington no doubt is at the core of America's national imaginary in which the nation has come, and continues to come, to an understanding of itself. Pictures of the nation's founder and savior testify to this-Gilbert Stuart's iconic "Athenaeum" portrait; also his "Lansdowne," which visualizes the legitimacy of a postrevolutionary, democratically elected president; the elder Peale's rendering of General Washington at Princeton; the younger Peale's Patriae Pater; or Emanuel Leutze's grandiose canvas of the crossing of the Delaware. Americans are familiar with these artworks from visits to the nation's museums, from prints, and other forms of reproduction.

Americans are also familiar with other paintings and engravings, plaster statuary and other art objects, the poetry, fiction, and drama written about Washington, the political discourses and inaugural addresses referring to him, as well as the medals and medallions, coins and currency, postage stamps, editorial cartoons, advertisements, calendars, book and magazine covers depicting him. In addition, Americans have acquired goods of all kinds with Washington's likeness on them, paperweights, dishes, crockery and other household goods and furnishings, handkerchiefs and other textiles, bottles, belt buckles, hats, hatchet-shaped cookie cutters, ice cream molds, fans, and other objects bearing his likeness. While the cultural historian Karal Ann Marling has dismissed these outpourings as simply junk (cf. 20-24), the values embedded in such traditions and practices are not without their force. They foster a sense of community. They offer a firm footing in the midst of social turmoil and economic chaos. They tender comfort and solace to those who feel orphaned, and they strengthen the bonds of union to the national community.

George Washington is alive also in Americans' everyday lives-on city landscapes, especially in the nation's capital, in the places named for him, in streets and businesses, in the hundreds of thousands of people that still carry his name, in the minds of people who leave "Happy Birthday" posts on the George Washington Facebook site, who bake George Washington meatloaves, or who around Father's Day 2018 disseminated on social media a Lansdownesque image of the nation's first president inscribed with 
"America, I am your father." The post drew any number of likes and comments, such as "Happy almost Father's Day to the Father of our Country," "I wish he could come back," "if you could only see your country today," or "we NEED him instead of this guy we got now" (Mount Vernon). And there is Washington's iconic portrait, which endures not just on the currency, but also has become the schoolroom Washington, the TV Washington, and a staple in popular print and media imagery. Businesses too love George Washington, who sells everything from coffee to soap to baking powder to soft drinks to cigars to travels to the most unlikely places. The face on the dollar bill advertises big February sales in department stores and used-car lots and it graces all kinds of objects, including T-shirts (worn, for instance, by students at George Washington University). Altogether, then, Washington's image not only has been internalized as an object but also has been transformed into a potent visual synecdoche for the nation, its economy, and its consumerist culture (cf. Thistlethwaite, “"Where Am I?"').

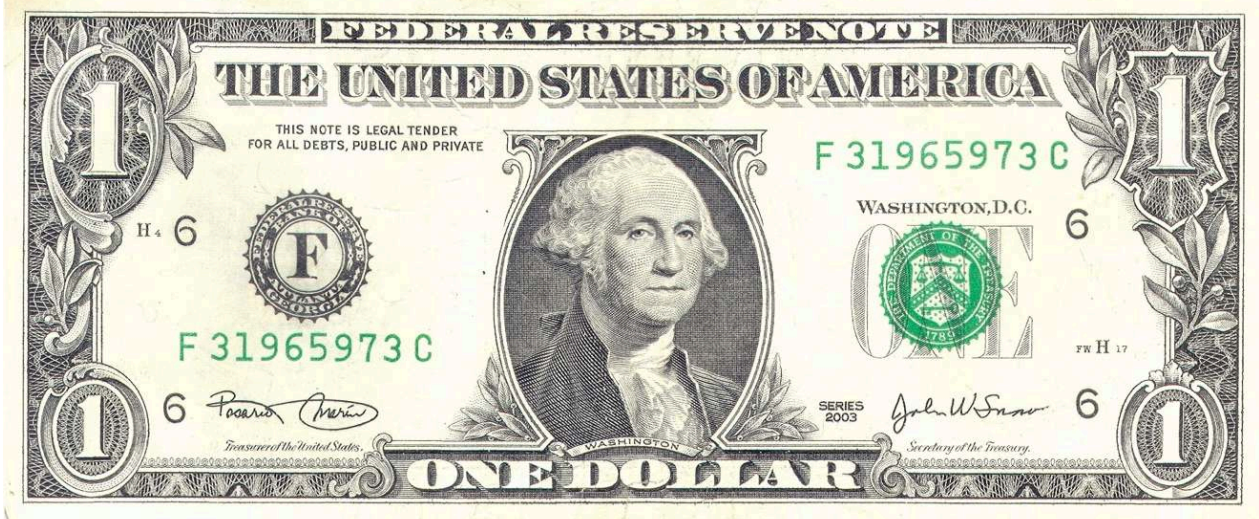

\section{(Source: Heinz Tschachler)}

On the one-dollar bill, Washington's iconic portrait represents a secular Lord, corresponding to the image or mark of the "prince," the familiar portrait of the ruler in the European tradition (cf. Foucault 175-76). In contrast, the Lord God is represented by a verbal image on the bill's back ("In God We Trust"). Each Lord can lay claim to a superior status, though Washington's status has the imprimatur of history and myth. Thus, the lyre-shaped frame surrounding his portrait can also be read symbolically, as OMEGA, the final letter in the Greek alphabet. The " $\Omega$ " represents the end of things or the glorious future the United States is looking forward to and working towards-in contrast to ALPHA, "A," which represents the beginning of things, hence God. Within this framework, Washington's portrait is symbolically linked with the past, beginning with God, and with the future, suggesting that the metaphorical father's spirit will continue to guide the nation's destiny. Whereas God the Father is the abstract deity of Christianity, George Washington is the metaphorical Father of His Country, the male link between citizens or subjects and the rest of the community, without whom the community is but "a formless mass" (Goux, "Numismatics" 11).

In England from the early seventeenth century, the role of the metaphorical father had fallen to the king. James I believed that he had to care for his subjects "like a father, for a King is truly Parens patriae, the politique father of his people." But what kind of father? In James's eyes, the king was "divine power on earth," authorized by God, and himself the ultimate authority over all earthly beings (Burrows and Wallace 170). The royalist doctrine of political absolutism changed with the Revolution Settlement of 
1688-1689, under which the king of Great Britain became a limited monarch who reigned under a constitutional framework commonly defined as a mixed government. The arrangement only cemented the patriarchal and familial political ideas and attitudes voiced in the North American colonists' eagerness to acclaim their sovereign as the "Father of His Country" (cf. Liddle 952-53). Yet fathers can fail, such as George III, who for many colonists was a "tyrant" neglecting his "children." This was the rage of unfulfilled expectations, a willful denial and suppression of a much-valued family connection: The "expected father of his people," Mason Weems wrote in his biography of Washington, "had looked on "the violation of American rights... with a most unfatherly calmness" (80).

While the American Revolution "destroyed all the earlier talk of paternal... government" (Wood 149-50), patriarchal language as such persisted. Nowhere is this clearer than in the eventual transfer, by an act a symbolic regicide and patricide, of the exalted title of "Father of His Country" from George III to George Washington. By this act of communal incorporation Washington became America's "living 'tribal' totem," hailed as the political father and head of a great people or, on the cover of an almanac published in Lancaster, Pennsylvania in 1778, as "Des Landes Vater" (cf. Baker 6; Albanese 144). A dictum common during the early years of the nation even said that "Providence" had left Washington childless so that the nation might call him "Father" (cf. Schwartz 173). The father trope, which readily salved the feelings of orphanhood among the revolutionaries, also became a staple of poems, speeches, portraits, namegiving and, not to forget, hagiographic biographies such as "Parson" Weems's Life. The ubiquity of the father trope indicates that from the beginning of the republic, Americans have understood the nation metaphorically in family terms, with the president seen at one and the same time as an older male authority figure and a privileged bearer of value. George Washington was called "the father of his country" partly because he was the metaphorical progenitor who brought it into being and partly because he was seen as the legitimate head of state, which in terms of the metaphor is the head of the family, the father. Americans still talk about their founding fathers, and it is not at all unreasonable for them to deploy them when in doubt about political matters. Additionally, to all presidents since Washington, and to all Americans, the presidency has been the office of national "fatherhood." When the United States goes to war, it sends its sons (and now also its daughters) into battle. A patriot (from the Latin pater, for "father") is not just a sophisticated guided missile but also someone who loves his or her fatherland.

31 All these terms suggest "family." This is not coincidental. As the linguist George Lakoff has argued, we are first governed in our families, and so we grow up understanding governing institutions in terms of the governing systems of families (cf. 153-61). Significantly, the "nation-as-family" metaphor provides the symbolic stage on which feelings of not belonging to or even being excluded from the national family, hence of fear, are acted out. "Fearful people," the philosopher Martha Nussbaum writes in her most recent book, "want protection and care. They turn to a strong and absolute ruler" (7). Thus to see even Donald Trump as "the father I always wanted" (qtd. in Geraghty) makes perfect sense. In psychological terms, such outpourings point to a desire for a paternal leader, one who, as Robin Lakoff stated in a political memorandum, is at one and the same time "a daddy, a king, a god, a hero... a champion who will carry that lance and that sword into the field and fight for us" (qtd. in Dowd). It's the rhetoric of political fatherhood, not motherhood, that ameliorates, if not elides, all kinds of fears, of 
change, of the future, of social decline, of other people. By the same token, the portraits on the currency of "the Presidents of the United States" serve as symbols of national consensus, continuity, and stability to which citizens are called upon to defer. Altogether, the metaphorical Fathers' "more permanent familiarity in the minds of the public" is to provide at least a semblance of stability in periods of domestic turmoil, and of continuity and comfort in times of international crisis and decline. They are the foundation of an aesthetic-theological-mythological scheme to strengthen the dollar from the outside, constituting an authority that guarantees permanence and stability.

No one will be fooled all the time, though. The "dead presidents" on modern dollar bills, together with the obligatory cultural memory they tap into and activate, are also symptoms of a profound crisis of patriarchy. ${ }^{7}$ Consider: Women have been entering the labor market in ever-larger numbers; they possess and use dollar bills on which they are not represented. True, there are monetary tokens on which women are depicted$\$ 1$ coins like the Anthony or the Sacagawea dollar-but these tokens have never been popular. Coins that do not circulate contribute nothing to stability and continuity. Nor are paper notes whose value is no longer backed by anything substantive and whose aesthetic design openly belies the economic logic of money. The metaphorical fathers on the currency therefore function as protective spirits-to maintain the belief that money as well as the acquisition of it, is a male prerogative. Patriarchy and ownership economy are, then, two sides of a coin (cf. Heinsohn and Steiger, chaps. 3 and 4). The "portraits of the Presidents" communicate a quasi-universal picture of patriarchal authority, based on private property over which owners have documented claims, and the state's welfare; at the same time, they conceal the fact that from the Constitutional Convention onward, America's "national subjectivity" has always been construed as "white" and "male" (cf. Nelson; Babb). From the beginning, the power of white males derived from the difference between one's own citizenship and that denied to other constituencies (women, African Americans, Native Americans). Today, this difference has become fragile. With the ideology of separate spheres as well as traditional constructions of masculinity eroding, fears and perceptions have come to the fore among white males that affirmative action, quotas, and preferences might bring gains for racial and ethnic groups and women, but only at their expense.

\section{Conclusion}

The portraits of "the Presidents of the United States" on the currency unambiguously emanate character and strength, at least as long as there is trust or confidence in the nation's currency and, importantly, as long as cash is not being replaced by "plastic money" or "electronic money." Though there are voices that consider a phase-out scenario as likely or even desirable (cf. Rogoff), all the evidence suggests that cash will continue to be the key medium for payment and the storage of value. According to the Federal Reserve, by December 31, 2015, a total of 38.1 billion dollar notes were in circulation, of which 11.4 billion were \$1 notes; in FY 2015 alone, the Bureau of Engraving and Printing delivered approximately 7.5 billion notes to the Federal Reserve, of which 2.425 billion were one-dollar notes (Board of Governors of the Federal Reserve System, "How much U.S. currency is in circulation?"). ${ }^{8}$ A major reason for the continuance of cash no doubt is that the bills carrying portraits of "the Presidents of the United States" tap into deeply felt needs and desires. How else can we 
explain the one-dollar bill's resilience against attempts to replace it with a coin? Economic reason-as John McCain noted, the switch from paper bills to coins would save some $\$ 4.4$ billion in currency production costs over the next 30 years-apparently is no match against people's emotions. To date, attempts to enact such legislation have not made it past committee review. And opinion polls have shown consistently that few Americans are prepared to give up their beloved "Georges." All this only confirms the sociologist Michael Schudson's belief that "the past is constantly being retold in order to legitimate present interests" and to elaborate present ideals and realities (qtd. in Schwartz 137).

As regards the past, Treasury Secretary Albert Gallatin in 1807 worried about a shortage of individuals qualified to hold office during the second Jefferson administration. When he suggested that the president consider hiring women, Jefferson replied by spilling out all the cultural understandings that have kept women from the public sphere to this very day: "The appointment of a woman to office is an innovation for which the public is not prepared, nor am I." And George Washington? It's a moot point to say that he also would not have been prepared to appoint a woman to office. There is no record that he ever was in a situation similar to President Jefferson's. What we can safely say is that the exalted title of Father of His Country at one and the same time immunized Washington against criticism and subverted ideological impetuses for further change, locking them into a "worthier" past. In that past, patriarchal language served to legitimize political authority. Americans or, rather, American males were accustomed to paternal authority. They honored their own fathers and expected their sons to honor them. Accordingly, political leaders who successfully donned the mantle of fatherhood not only elicited considerable citizen respect and deference; they could also rest assured that for most people dissent was too daunting. As Reid Mitchell put it, "[t]he parental metaphor made rebellion a primal sin" (116).

Another consequence of the parental metaphor has been more far-reaching. Since patriarchal leadership was associated with "benign authority," a man could obey a biological or political father without feeling that he forfeited his manly independence or citizenship. This seems true even today. For, the hopes and anxieties associated with Washington's successors unambiguously demonstrate a desire for a paternal leader. As sobering as it may sound, therefore, all the evidence suggests that "a woman leading the United States is not, as many young voters predicted this election cycle, simply a matter of time" (Friedman). Nor is the appearance of a portrait of a woman on the currency simply a matter of time. The currency, I have tried to show in these pages, is one of the many ways in which the state tells its stories to its citizens. "Monetary space is sovereign space," the British sociologist and political scientist Geoffrey Ingham stated (57). Unsurprisingly, the pictures on America's coins and currency have been routinely used by the United States government to disseminate stories of national heroes (and villains). While these repetitive images contribute towards building a national identity, none of the stories springs up spontaneously or "naturally." On the contrary, they are always constructed, propagated, and passed on with a view to the maintenance of power. As George Gerbner noted, "[t]hose who tell stories hold the power in society" (9). For the state, this power consists in manufacturing consent, that is, in conveying beliefs, convictions, or moral values that will be broadly shared. It is the manufacturing of consent, the ingraining in the popular unconscious of a set of 
values and beliefs, that allows the state to imagine the people under its dominance, the geographic territory under control, and the nature of historical legitimacy.

\section{BIBLIOGRAPHY}

Albanese, Catherine L. Sons of the Fathers: The Civil Religion of the American Revolution. Philadelphia: Temple UP, 1976.

Americans for George. 27 Apr. 2012. https://www.facebook.com/amerforgeorge.

Babb, Valerie Melissa. Whiteness Visible: The Meaning of Whiteness in American Literature and Culture. New York-London: New York UP, 1998.

Baker, William S. Bibliotheca Washingtoniana: A Descriptive List of the Biographies and Biographical Sketches of George Washington. Philadelphia: Robert M. Lindsay, 1889.

Board of Governors of the Federal Reserve System. "Currency in Circulation: Volume." 5 Feb. 2016. Jan. 2017. https://www.federalreserve.gov/paymentsystems/coin_currcircvolume.htm.

---. "How much U.S. currency is in circulation?” 25 Oct. 2016. Jan. 2017, https://

www.federalreserve.gov/faqs/currency_12773.htm.

Boesenberg, Eva. "Self-made Women, Spent Men? Money and Gender in U.S. American Novels since the 1980s." Almighty Dollar: Papers and Lectures from the Velden Conference. Ed. Heinz Tschachler, Eugen Banauch, and Simone Puff. Wien-Münster: LIT Verlag, 2010. 159-80.

Bowers, Q. David. Whitman Encyclopedia of U.S. Paper Money. Atlanta, GA: Whitman Publishing, 2009.

Burrows, Edwin G., and Michael Wallace. "The American Revolution: The Ideology and Psychology of National Liberation.” Perspectives in American History 6 (1972): 167-306.

Clinton, Hillary Rodham. What Happened. New York: Simon \& Schuster, 2017.

Coolidge, Calvin. The Price of Freedom: Speeches and Addresses. 1924. Amsterdam: Fredonia Books, 2001.

Deutsche Bundesbank, "Das besondere Objekt. Ästhetik und Sicherheit - Weltbanknoten der Jahre 2005 bis 2009." 24 Nov. 2010. http://www.bundesbank.de/Redaktion/DE/Downloads/ Bundesbank/Geld_Kunstsammlung/aesthetik_und_sicherheit_weltbanknoten.pdf?

_-_blob=publicationFile.

Dowd, Maureen. “The 1992 Campaign.” The New York Times. 10 Oct. 1992. Feb 2018. http:// www.nytimes.com/1992/10/10/us/1992-campaign-political-memo-knights-presidents-racemythic-proportions.html?pagewanted=all\&pagewanted=print.

Elshtain, Jean Bethke. Public Man, Private Woman: Women in Social and Political Thought. Princeton, NJ: Princeton UP, 1981.

Ferguson, Robert A. The American Enlightenment, 1750-1820. Cambridge, MA: Harvard UP, 1997.

Foucault, Michel. The Order of Things: An Archaeology of the Human Sciences. New York:

Pantheon, 1970. 
Friedman, Uri. "Why It's So Hard for a Woman to Become President of the United States." The Atlantic. 12 Nov. 2016 Mar 2018. https://www.theatlantic.com/international/archive/2016/11/ clinton-woman-leader-world/506945/.

Frizell, Sam. “Donald Trump Says Harriet Tubman on the \$20-Bill is 'Political Correctness'." Time 21 Apr. 2016 Jan 2017. http://time.com/4303332/donald-trump-says-harriet-tubman-on-the-20bill-is-political-correctness/.

Furnham, Adrian, and Michael Argyle. The Psychology of Money. London-New York: Routledge, 2007.

Geraghty, Jim. “Donald Trump Is Not Your Father,” National Review 26 Apr. 26, 2016 May 2017. http://www.nationalreview.com/article/434570/donald-trump-not-your-father.

Gerbner, George. “Society's Storyteller: How TV Creates the Myths by Which We Live.” Media \& Values 40-41 (Summer/Fall 1987): 8-9.

Gilbert, Emily. “'Ornamenting the Façade of Hell': Iconographies of 19th-Century Canadian Paper Money." Environment and Planning D: Society and Space 16 (1998): 57-80.

Goodwin, Jason. Greenback: The Almighty Dollar and the Invention of America. New York: Henry Holt, 2003.

Gordon-Reed, Annette. “Female Trouble.” The New York Review of Books LXV:2 (February 8, 2018): 12-14.

Goux, Jean-Joseph. "Cash, Check, or Charge?" The New Economic Criticism: Studies at the Intersection of Literature and Economics. Ed. Martha Woodmansee and Mark Osteen. New YorkLondon: Routledge, 1999. 114-27.

---. The Coiners of Language. Trans. Jennifer Curtiss Gage. Norman: U of Oklahoma P, 1994.

---. Symbolic Economics: After Marx and Freud. Trans. Jennifer Curtiss Gage. Ithaca, NY: Cornell UP, 1990.

Greenwood, Max. "Trump hangs portrait of Andrew Jackson in Oval Office." The Hill 25 Jan. 2017. http://thehill.com/homenews/administration/316115-trump-hangs-portrait-of-andrew-jacksonin-oval-office.

Haberman, Maggie. "A Homebody Finds the Ultimate Home Office.” The New York Times 25 Jan. 2017. https://www.nytimes.com/2017/01/25/us/politics/president-trump-white-house.html? _r=1.

Harris, Marvin. Cannibals and Kings: The Origins of Cultures. New York: Vintage, 1991.

Heinsohn, Gunnar, and Otto Steiger. Ownership Economics: On the Foundations of Interest, Money, Markets, Business Cycles, and Economic Development. Abingdon, UK-New York: Routledge, 2013.

Helleiner, Eric. The Making of National Money: Territorial Currencies in Historical Perspective. Ithaca, NY: Cornell UP, 2003.

Hymans, Jacques E. C. "The Changing Color of Money: European Currency Iconography and Collective Identity." European Journal of International Relations 10:1 (March 2004): 5-31.

Ingham, Geoffrey. The Nature of Money. Malden, MA: Polity Press, 2004.

Irigaray, Luce. The Sex which is Not One. Ithaca, NY: Cornell UP, 1985

Jefferson, Thomas. Thomas Jefferson to Albert Gallatin, 13 Jan. 1807. Founders Online. National Archives Mar 2018. http://founders.archives.gov/documents/Jefferson/99-01-02-4862. 
Lakoff, George. Moral Politics: How Liberals and Conservatives Think. 2nd ed. Chicago: U of Chicago P, 2002.

Lauer, Josh. "Money as Mass Communication: U. S. Paper Currency and the Iconography of Nationalism." The Communication Review 11 (2008): 109-32.

Liddle, William D. “'A Patriot King, or None': Lord Bolingbroke and the American Renunciation of George III.” Journal of American History 65:4 (March 1979): 951-70.

Marling, Karal Ann. George Washington Slept Here: Colonial Revivals and American Culture, 1876-1986. Cambridge, MA: Harvard UP, 1988.

“Martha on \$1." George Washington's Mount Vernon. N.d. Sept. 2017. http://

www.mountvernon.org/george-washington/martha-washington/martha-on-1/.

Marx, Karl. A Contribution to the Critique of Political Economy [1859]. Trans. W. I. Stone.

Chicago: Charles H. Kerr, 1904.

Mitchell, Reid. The Vacant Chair: The Northern Soldier Leaves Home. New York: Oxford U P, 1993.

Mount Vernon. “America, I am your father.” 15 Jun. 2018. https://www.instagram.com/p/

BkDfo10jl6_/?hl=en\&taken-by=mount_vernon

Nelson, Dana D. National Manhood: Capitalist Citizenship and the Imagined Fraternity of White Men. Durham, NC: Duke UP, 1998.

Nussbaum, Martha. The Monarchy of Fear: A Philosopher Looks at Our Political Crisis. New York: Simon \& Schuster, 2018.

Pointon, Marcia. "Money and Nationalism." Imaging Nations. Ed. Geoffrey Cubitt. Manchester, UK: Manchester UP, 1998. 229-54.

Poovey, Mary. Uneven Developments: The Ideological Work of Gender in Mid-Victorian England. Chicago: U of Chicago P, 1998.

“President Donald Trump's Remarks at Andrew Jackson's Hermitage." 15 Mar. 2017. https:// www.youtube.com/watch?v=thx5_2jfpiU.

Rogoff, Kenneth S. The Curse of Cash: How Large-Denomination Bills Aid Crime and Tax Evasion and Constrain Monetary Policy. Princeton, NJ: Princeton U P, 2016.

Schwartz, Barry. “A New Man for a New Century.” George Washington: American Symbol. Ed. Barbara L. Mitnick. New York: Hudson Hills Press, 1999. 123-39.

Second Presidential Debate. New York Times, 9 Oct. 2016. http://www.nytimes.com/2016/10/10/ us/politics/transcript-second-debate.html?ribbon-ad-

$\mathrm{idx}=11 \& \mathrm{rref}=$ politics\&module=Ribbon\&version=origin\&region=Header\&action=click\&contentCollection=Politics\&pgtype=article .

Skaggs, David Curtis. "Postage Stamps as Icons." Icons of America. Ed. Ray B. Browne and

Marshall W. Fishwick. Bowling Green, OH: Bowling Green State U Popular P, 1978. 198-208.

Smithers Pira. "Fit for Circulation: The Future Lifecycles of Currency to 2026." 31 Jul. 2016. Jan.

2017. http://www.smitherspira.com/industry-market-reports/security/banknotes/life-

expectancy-of-currency-forecasts-to-2026.

---. "The Future of Banknotes to 2021." 11 Dec. 2016 Jan. 2017. http://www.smitherspira.com/ industry-market-reports/security/banknotes/the-future-of-banknotes-to-2021.

Thistlethwaite, Mark E. The Image of George Washington: Studies in Mid-Nineteenth-Century American History Painting. New York: Garland, 1979. 
---. “'Where Am I?': Tracking George Washington's Dollar Bill Image.” Paper given to “Rethinking National Foundations: Using/Abusing History." American Comparative Literature Association Conference, Harvard University, March 17-20, 2016.

Tschachler, Heinz. The Greenback: Paper Money and American Culture. Jefferson, NC: McFarland, 2010.

United States Congress. “All Bill Information (Except Text) for H.R.2977 - Currency Optimization, Innovation, and National Savings Act." Dec 2016. https://www.congress.gov/bill/112thcongress/house-bill/2977/all-info.

United States Congress. “S.1888, USA Act.” 29 Jul. 2015 Aug 2018. https://www.congress.gov/bill/ 114th-congress/senate-bill/1888.

United States Department of the Treasury Bureau of Engraving and Printing (USBEP). "FAQs." N.d. Aug 2017. http://www.bep.gov/resources/faqs.html.

Weems, Mason L. The Life of George Washington. Philadelphia: Joseph Allen, 1837.

Women on 20s. “Awaiting Treasury Timeline.” Aug 2018. http://www.womenon20s.org/.

Wood, Gordon S. The Radicalism of the American Revolution. New York: Knopf, 1992.

\section{NOTES}

1. As Hillary Clinton writes in her memoir, historically, “women haven't been the ones writing the laws or leading the armies and navies... It's the men who lead. It's the men who speak... That's been the case for so long it has infiltrated our deepest thoughts" (223).

2. The figures are impressive: Between 1861 and 1900 more than 160 different types, classes, and varieties of bank notes were put in circulation. By 1929, the number was cut in half; as of 1930, only 15 were left (cf. Lauer 121-24).

3. The word "presidents" is, strictly speaking, a misnomer. The committee's decision was somewhat altered by the Secretary of the Treasury, the USBEP explains, to include Hamilton (on the new $\$ 10$ bill), the fledgling nation's first Secretary of the Treasury; Salmon P. Chase (on the new $\$ 10,000$ bill), Secretary of the Treasury under Lincoln and credited with promoting the National Banking System; Benjamin Franklin (on the new $\$ 100$ notes, the "Benjamins"), one of the signers of the Declaration of Independence and, together with John Adams and John Jay, of the Paris Peace Treaty of 1783. "All three of these statesmen," the USBEP concludes, "were well known to the American public."

4. The "conservatism" of currency design is a major reason that the presence of women on U.S. stamps is much more satisfactory than on bank notes (cf. Skaggs).

5. Not simply "ein Gegenstand des täglichen Gebrauchs für jedermann ... als Werbeträger sollte sie ein Spiegelbild der Werte sein, die sie repräsentiert, wie Stabilität, Kontinuität und Krisenfestigkeit... Daher wird die Banknote gelegentlich auch als Visitenkarte eines Staates bezeichnet" (Deutsche Bundesbank).

6. For a good example of the state-as-teacher approach to currency iconography, see Helleiner; for an elaboration of the state-as-legitimacy-seeker approach, see Hymans. Emily Gilbert, too, explores the connection between currency iconography and the ideological purposes it serves. 7. "Dead presidents" is a well-known and often-used colloquialism, though it's well worth revealing it to itself. "Fathers," Jean-Joseph Goux notes, can fulfill their privileged roles only as long as they are separated, kept at a distance from the "family," 
that is, the larger whole. Phrased differently, "fathers" can ascend to symbolic heights and assume transcendence only as "dead fathers," their place reduced to the "Name-ofthe-Father" ("Numismatics" 18, 49).

8. Worldwide some 180 to 190 billion notes of all kinds are in circulation, at an estimated value of $\$ 4.3$ trillion (about 8.3 per cent of the money in the world). Global annual production of notes is estimated at 85 to 95 billion notes, at an estimated market value of $\$ 11.5$ billion, and rising at an annual rate of 5.5 per cent; by 2026, therefore some 943 billion bank notes (as well as 179 billion coins) will be circulating worldwide (cf. Board of Governors of the Federal Reserve System, "Currency in Circulation: Volume"; Smithers Pira, "Fit for Circulation: The Future Lifecycles of Currency to 2026," and "The Future of Banknotes to 2021").

\section{ABSTRACTS}

When in April 2016, the United States Department of the Treasury officially announced the redesign of the $\$ 20$ bill, the plan provided that the portrait of an "exemplary American woman" would replace Andrew Jackson's. This article explores whether such a portrait would make any substantive difference to women's marginalization in public life. It interprets the exclusive presence of portraits of "Presidents" on the nation's currency as tantamount to the real power of men in society and, as well, to a metaphorical understanding of the nation in family terms. Indeed, from the beginning of the republic the president has been seen at one and the same time as an older male authority figure and a privileged bearer of value. All the evidence suggests, therefore, that the appearance of a portrait of a woman on the currency is more than simply a matter of time, just as there is little evidence that a woman leading the United States is simply a matter of time.

\section{INDEX}

Keywords: U.S. currency, graphic design, ideological purposes of currency iconography, absence of women on currency, marginalization of women in public, rhetoric of political fatherhood, persistence of patriarchy

\section{AUTHOR}

\section{HEINZ TSCHACHLER}

Heinz Tschachler is a former Associate Professor of English and American Studies at AlpenAdria-Universität Klagenfurt. His academic interests are relations between representation, ideology, and material conditions as well as, more recently, cultural aspects of America's money. He believes that coins and currency not merely encourage trade and investment but are at the same time cultural products that speak to the identity of a group of people, a place, and a time. He has written numerous articles on America's money, edited a conference volume (Almighty Dollar, 2008), and published four monographs, including The Greenback (2010) and Americans for George (2015). 